\title{
Patterns of tuberculosis in the Americas - How can modern biomedicine inform the ancient past?
}

\author{
Alicia Kay Wilbur ${ }^{+}$, Jane Ellen Buikstra \\ Center for Bioarchaeological Research, School of Human Evolution and Social Change, Arizona State University, \\ Tempe AZ 85287, US
}

Tuberculosis (TB) is an infectious disease that continues to take its toll on human lives. Paleopathological research indicates that it has been a significant cause of death among humans for at least five thousand years. Because of the devastating consequences to human health, social systems, and endangered primate species, TB has been the subject of many and varied research efforts throughout the world, efforts that are amassing an enormous amount of data concerning the causative agent Mycobacterium tuberculosis. Despite sequencing of the M. tuberculosis genome and numerous molecular epidemiological studies, many questions remain regarding the origin, evolution, and future co-evolutionary trajectory of M. tuberculosis and humans. Indeed, the origin of pre-Columbian New World TB has been and remains hotly debated, and resolution of this controversy will likely only come with integration of data and theory from multiple disciplines. In this paper, we discuss the pre-Columbian TB controversy, and then use research from biological and biomedical sciences to help inform paleopathological and archaeological studies of this ubiquitous disease that plagued our ancient forbears.

Key words: tuberculosis - Americas - Maya - anemia - paleopathology - iron

Tuberculosis (TB) is an infectious disease caused by species of the genus Mycobacterium. In mammals, TB is most often caused by members of the Mycobacterium tuberculosis complex: M. tuberculosis, M. africanum, and $M$. canettii, which are primarily pathogens of humans, and $M$. microti and M. bovis, which primarily affect other mammals. Immune-compromised humans can also be infected by and develop disease from the M. avium complex, usually a bird pathogen, as well as some environmental saprophytes such as M. ulcerans and M. marinum. Among mammals, the route of infection with the $M$. $t u$ berculosis complex is typically via affected droplets coughed or sneezed from the lungs - these are then inhaled (or occasionally ingested) by close contacts (Myers \& Steele 1969, Fanning 1994).

In the early and middle XX century, the prevailing belief was that TB evolved in the Old World, and was brought to other parts of the world following contact with European explorers and colonists. Medical doctors (Hrdlicka 1909, Morse 1961, Cockburn 1963) studying the New World archaeological record supported the idea with what they felt were key pieces of evidence against preColumbian New World TB. Hrdlicka and Morse, for example, emphasized the absence of anecdotal evidence of the disease from early explorers, colonists, and Native Americans themselves; the lack of TB lesions in pre-contact skeletons; and the extreme susceptibility of Native American groups to the disease upon European contact.

Fiancial support: Smithsonian Institution to JEB

${ }^{+}$Corresponding author: alicia.wilbur@asu.edu

Received 20 July 2006

Accepted 16 October 2006
Cockburn further stressed that Native Americans exhibited characteristics of populations naïve to $\mathrm{TB}$, underscoring the apparent high prevalence in all age groups and overall high mortality, and the tendency for individuals to exhibit glandular rather than pulmonary TB. Further, he argued that TB was a crowd disease, requiring large, settled populations or a domestic animal to serve as an origination point and reservoir for the disease, neither of which was believed to have existed.

In 1944, Rich had suggested that, because M. bovis has such a wide host range relative to $M$. tuberculosis, it was probably the ancestral form, with $M$. tuberculosis a natural mutant that then specialized in humans. Following this line of reasoning, Cockburn (1963) posited that TB originated in the Old World with cattle domestication - because the New World was colonized prior to the domestication of cattle in the Old World, it would have been impossible for M. tuberculosis to exist in the preColumbian New World.

While the above scenario seemed reasonable and was widely accepted, it did not fit with the biological and archaeological evidence from the New World. Pre-Columbian skeletal remains with lesions strongly resembling those diagnostic of TB have been recovered from many different sites in the Americas (García-Frías 1940, Requena 1945, Lichtor \& Lichtor 1952, Ritchie 1952, Judd 1954, Crane \& Griffin 1959). By the mid-XX century, accumulated evidence for pre-Columbian TB, including the discovery of TB-like lesions in pre-Columbian Peruvian mummies (Allison et al. 1973) led paleopathologists to hypothesize that $M$. tuberculosis was, after all, present in the Americas prior to contact (Buikstra 1976,1999). After assessing the evidence for pre-Columbian TB, Buikstra (1976) analyzed the arguments developed by Hrdlicka, Morse, and Cockburn, emphasizing several important points: the incomplete nature of early ethnohistoric and ethnographic accounts, the impact of antibiotic therapy upon contem- 
porary clinical experience, the presence of large urban centers throughout the Americas, and the presence of potential animal reservoirs. It was further noted that Cockburn's “naïve" patterning didn't appear until groups were resettled onto reservations or repartimientos.

By the 1990s, the development of molecular techniques such as the polymerase chain reaction (Mullis \& Faloona 1987) made possible the direct analysis of ancient pathogens when preservation permitted. A diagnostic, repetitive DNA fragment from the $M$. tuberculosis complex was obtained from ancient pre-Columbian individuals with TB-like lesions from sites in North and South America by several groups. The first research focused upon desiccated soft tissues (Salo et al. 1994), but this was soon followed by evidence recovered from bones (Arriaza et al. 1995, Braun et al. 1998).

Recent biomolecular studies on the genome of modern M. tuberculosis complex strains indicates that $M$. bovis arose from an M. tuberculosis-like precursor (Brosch et al. 2002, Baker et al. 2004, Gutierrez et al. 2005), and thus was not ancestral to $M$. tuberculosis. Further, if results of Rothschild et al. (2001) are valid, then ancient M. tuberculosis DNA was present in an extinct long-horned bison from Wyoming some 17,870 years ago.

Despite paleopathological and molecular evidence for ancient pre-Columbian tuberculosis, controversy still remains. Molecular evidence has not been accepted by all. Especially vocal critics thought that the recovered genetic material was likely contamination by modern organisms, or if authentic ancient DNA, it was from M. bovis rather than M. tuberculosis, following the viewpoint that M. tuberculosis initially arose from Old World cattle (Stead et al. 1995). Other criticisms focused upon the susceptibility of Native American groups after initial contact with European conquerors and colonists, hypothesizing that the "ancestral" condition for humans is susceptibility to TB (Stead 1997, 2001). In this scenario, Europeans were least susceptible to TB because they had encountered it longer than any other group. The high morbidity and mortality observed among Native Americans was due to immunological "naïveté" to the pathogen, and therefore pre-Columbian TB could not have existed in the New World:

"Some [paleopathologists] have erroneously deduced that TB as we know it today must have existed before \{Columbus\} got here. If they had been correct, the Indians would not have been decimated by TB when they were crowded into reservations" (Stead 2000).

Among the unstated assumptions in the above quote are two that are crucial for an understanding of TB among New World natives. The remainder of this paper focuses on these assumptions, and presents examples of ways in which integration of data and theory from fields in biology and biomedicine can provide a broader understanding of the ancient, and complicated, paleopathological record.

\section{Factors affecting host responses to pathogens}

A more thorough examination of the issue of Native American susceptibility to TB, and certainly the issue of pre-Columbian TB, should include work of evolutionary biologists and epidemiologists on host/pathogen co-evolution, immunological history of the host population, genetic diversity present in both the host and pathogen, and host dietary and nutritional factors. Examples of how these factors may influence our understanding of Native American susceptibility to TB and its meaning in regard to possible pre-Columbian TB follow.

Social and cultural disruption can increase susceptibility to infectious disease - The first assumption in the above quotation is that the social and cultural consequences of European contact and colonization to Native American communities were negligible. In fact, social disruption, forced relocation and/or concentration onto reservations or other inhospitable environments, extreme poverty, malnutrition, huge increases in population density, and exposure (often in heavy dosages) to many different pathogens, were all consequences of European contact and colonization that increased susceptibility to disease in general. Experimental research by Power et al. (1998), for example, showed that high doses of mycobacteria caused inefficient immune responses that precipitated disease. The authors speculated that "[i]t is natural to suppose that crowded living conditions will lead more often to the substantial infection required to establish disease". It is highly likely, then, that the high population densities resulting from widespread relocation and concentration of native groups was one of the most important factors in contact-era susceptibility to respiratory diseases.

The host-pathogen co-evolutionary trajectory depends on multiple factors - The second assumption embedded in the previously-cited quotation is that pathogens always advance toward benign forms, and/or that hosts always evolve immunity over time. However, several examples of pathogens that have not developed benign coexistence with humans come to mind: the influenza virus is documented historically from at least 15 th century Europe, and probably long before (Kuszewski \& Brydak 2000), and is still a significant cause of death in many parts of the world, even in developed nations (WHO 2003). This intracellular virus can modify its antigen structure to overcome host defenses, and annual flu cycles are lethal to some individuals, even with access to vaccination and excellent healthcare. Closer to the topic at hand, the evolution of drug-resistant strains of TB in many parts of the world where humans and M. tuberculosis have been in contact over time, and the emergence of extremely virulent strains of M. tuberculosis in some areas (for example, the Beijing variant; van Soolingen et al. 2005) also tend to belie the assumption that association over time always leads to benign commensalism. While there are many, and varied, reasons for the emergence of drug-resistance and virulence, the point is that a long period of interaction is only a single factor influencing the co-evolutionary trajectory a host and pathogen will take.

The immunological history of the host population There are two basic types of acquired immunity in humans: the cell-mediated or T-helper 1 (Th1) response, and the antibody producing, or T-helper 2 (Th2) response 
(Mosman et al. 1986). Although all healthy humans are capable of making both responses, the two tend to down regulate each other (Sander et al. 1995 and reviewed in D'Ambrosio et al. 1998). The Th1 response is that which is most effective against intracellular infections such as M. tuberculosis (Surcel et al. 1994) while the Th2 response is most effective against macroparasites.

Hurtado et al. (2003) have found that Native South Americans constantly encounter macroparasites in their environments. The Yanomamo, for example, show some of the world's highest levels of antibodies (Sousa et al. 1997, Hurtado et al. 2003) even when they are healthy, and this is thought to be due to the constant stimulation of the Th2 pathway by macroparasites. Perhaps more germane to an understanding of Native American responses to TB is the report from Hurtado et al. (2003) that among the Aché of Paraguay, a large number of individuals are incapable of making a delayed-type hypersensitivity (Th1type) response to challenge with the tuberculin purified protein derivative test, even though there are high rates of TB in this population. In fact, individuals who either have active TB or who have a history of active (treated) TB are still unable to make a Th1 response, as are individuals who have $M$. tuberculosis DNA present in their mouths (and hence are exposed; Wilbur 2005). Thus, this exposed and infected group reacts as if it is immunologically "naïve" to the pathogen! This highlights the important role of the immune history of contact-era Native American populations in their reactions to TB, and severs any simple, direct link that might be made between susceptibility to TB and prior existence of the disease.

The genetic structure of the host population (see Anderson \& May 1982, Ewald 1994) - When an infectious bacterium encounters a large population with appreciable variation at immune loci, potential hosts may vary widely in susceptibility and resistance to the bacterium. In this case, the probability of the pathogen encountering a new susceptible host quickly may be low. Here it is to the evolutionary advantage of the pathogen to become fairly benign, as virulence would lead to quick death of the host and an evolutionary dead end of the organism if a new susceptible is not encountered.

In a homozygous population, however, there is an abundance of available hosts. In this case, the bacterium that can infect a host, multiply rapidly, and infect many new hosts is at an evolutionary advantage - therefore, increased virulence is favored. Evidence thus far indicates that many Native American populations are genetically homogeneous at many loci (Salzano 2002, Mulligan et al. 2004), including those of the immune system (Wilbur 2005). In the wake of wars, poverty, starvation and waves of other diseases, heterozygosity was likely drastically reduced in contact-era Native Americans, leading to increased virulence among bacterial pathogens such as $M$. tuberculosis.

Diet and nutrition influence the course of disease - A final detailed example focuses on the pattern of presence and absence of New World archaeological evidence for TB, and synthesizes current epidemiological and molecular biological research with the archaeological record.
Many convincing cases of pre-Columbian miliary TB in South America and North America north of Mexico have been recorded by paleopathologists and documented with ancient DNA (reviewed in Buikstra 1999, Roberts \& Buikstra 2003). By contrast, the ancient Maya present either none or a very few convincing cases of disseminated TB. Given that there were densely populated urban centers as well as long distance trade with areas of both North and South America (Buikstra 1999, Roberts \& Buikstra 2003), complete absence of TB among the ancient Maya would be remarkable. Three broad hypotheses can be set forth to explain this apparent absence.

Hypothesis 1 - There was, indeed, no tuberculosis present among the ancient Maya. This could have been possible if either or both of the following were the case: (a) the ancient Maya were isolated from populations in which TB was prevalent - Given that disseminated TB is documented in the Greater Southwest by the XVII/XIX centuries A.D. (Buikstra 1999, Roberts \& Buikstra 2003), its virtual absence from Mesoamerica prior to late precontact times remains enigmatic. There are two cases from West Mexico as early as the XI century AD, while three more from the Mexico City area date to late pre-Colonial times. Yet, large population aggregates and long distance trade have characterized northern Mesoamerica since preClassic times (Sharer 1994). While the patterns of interaction changed over time and trade routes altered, certainly an infectious disease such as TB should have spread throughout this region, as it was present in the Greater Southwest by Late Classic times. Population sizes were sufficient and while regionalized trading patterns developed during post-Classic times (Lorenzo 1995), it is difficult to believe that the region would have been sufficiently isolated to deter the spread of TB; (b) the ancient Maya were somehow resistant to infection and disease from $M$. tuberculosis - A large body of research throughout the world has examined host differences in susceptibility and resistance to M. tuberculosis in humans and other mammals (reviewed in Bellamy \& Hill 1998, Wilbur 2005). Even among inbred laboratory animals, however, there is variation in susceptibility, and to date no population of humans has ever been found with complete resistance to $M$. tuberculosis. Further, modern Native American groups have shown high susceptibility to infection and disease from the organism (Sousa et al. 1997, Hurtado et al. 2003, Wilbur 2005). It is thus unlikely that the ancient Maya were resistant to M. tuberculosis.

Hypothesis 2 - Infection and even disseminated disease from M. tuberculosis were present among the ancient Maya, but these have not been recovered for various reasons: (a) poor preservation precludes recovery of individuals with skeletal TB - While Maya sites are notorious for poor bone preservation, it is hard to believe that Pott's disease, with its effusive bone formation, would not have been preserved somewhere in the Maya realm. As will be emphasized below, there is evidence for nutritional stress among the ancient Maya, whose thus compromised immune systems may have led to death relatively early in the course of the disease, before dissemination could occur. Other similarly compromised groups 
from North America, however, present clear evidence of bone TB; (b) as yet undocumented mortuary customs resulted in differential disposal areas for individuals with skeletal TB - Individuals dying with obvious skeletal deformation could have been treated distinctively following death, perhaps through spatial isolation or bodily destructive mortuary treatments (Buikstra 1999, Roberts \& Buikstra 2003). Dwarfs, for example, are artistically represented in many ancient Maya contexts, yet only one skeleton with possible dwarfism has been reported - Tikal Burial 24 Structure 5D-33-1st (Coe 1990, Prager 2002). Even this example, with its short stature apparently reconstructed from either field drawings $(115 \mathrm{~cm})$ or in situ crown-heel length (125 cm, as accepted by Haviland 1967), is reported to have long legs of somewhat normal size (p. 322) relative to a kyphotic spine (Coe 1990) Dwarfism is clearly a possibility, though the impact of vertebral kyphosis upon stature estimates is unknown, as the remains are not presently available for study (Lori Wright, pers. commun., Nov. 19, 2005). Most dwarfs figured artistically by the ancient Maya appear to have suffered from achondroplasia, which is not the likely diagnosis in this example. Bautista Marínez and Romano Pacheco (2003) do, however, report an achondroplastic dwarf skeleton, recovered from a west Mexican context. Foot deformity in a burial from Tikal has also been described (Wright 2005), and individuals with spinal deformities not attributable to TB, including osteoarthritis, osteophytosis, and ankylosing spodylitis have been recovered from Maya archaeological sites (Tiesler \& Cucina 2005). Thus, an apparent low recovery rate for individuals with deforming pathology lends modest support to theories emphasizing sampling bias based upon selective interment practices.

Hypothesis 3 - Tuberculosis was present among the ancient Maya, but for some reason dissemination from the lungs to the skeleton was extremely rare. This could potentially be attributable to either pathogen differences or to host differences: (a) differences in the strain of $M$. tuberculosis resulted in a different manifestation of disease - i.e., hematogenous dissemination did not occur. There is evidence from modern molecular studies that some strains of $M$. tuberculosis are more virulent than others (e.g., Dunn \& North 1995). While it is possible that a morevirulent strain that killed individuals quickly left no bone lesions, it is uncertain how biologically plausible this is. However, even if different strains of $M$. tuberculosis were present among the ancient Maya than among North and South American natives, it is expected that with trade, the more virulent strain would have moved into any new population contacted. Thus, even if Maya had a more virulent strain that led to earlier death, and no dissemination, it is expected that upon contact with North and South Americans the more virulent strain would have been transmitted to the traders. Assuming that the traders then returned to their people and transmitted the new virulent strain, the archaeological record should a lack of TB in North and South American populations who previously showed disseminated TB.

Assuming high virulence, there would be a trend of this absence of TB as temporal and geographic distance from Maya trade routes decrease. Although temporal regional control of the archarological record is difficult, what is certain is that once introduced into the Greater Southwest, a disseminated form of TB persisted throughout the pre-Colonial period (Roberts \& Buikstra 2003); (b) differences in the Maya hosts themselves resulted in a different manifestation of disease - This could have taken the form of reduced infection and disease, which were already discussed above in terms of host genetics. One might posit cultural practices that prevented infection with $M$. tuberculosis despite exposure to the organism, but such mechanisms have eluded modern public health officials for decades, despite attempts to find and implement them; (c) exposure to other pathogens in the Maya environment somehow rendered the population immune to disseminated TB - If, for example, the ancient Maya typically encountered other pathogens that encouraged a Th1 response, such would have helped them to successfully fight off TB infection and disease. However, this has not been observed at a population-wide level anywhere in the modern world to our knowledge, and in any case, at least among modern Maya, pathogens encouraging both Th1 (e.g., species of the genus Leishmania) and Th2 (e.g., helminths) types of immune responses are known to be endemic (Whittington 1989); (d) diet/nutrition influenced host response to exposure and infection with $M$. tuberculosis - Published sources related to diet and nutrition define two general patterns for ancient Maya. First is the widespread evidence of heavy reliance on maize consumption (Whittington 1989, Wright 1994, Chase 1997, Massey \& Steele 1997, Saul \& Saul 1997, Whittington \& Reed 1997). The second is the apparent porotic hyperostosis and cribra orbitalia in large numbers of individuals at the sites of Corozal, Caracol, and Tayasal (Chase 1997), Cuello (Saul \& Saul 1997), Colha (Massey \& Steele 1997), Copán (Whittington \& Reed 1997, Whittington 1989). Maya researchers have attributed the porotic hyperostosis and cribra orbitalia to iron-deficiency anemia secondary to an extraordinary reliance upon maize, which is iron-poor (see, for example, Whittington 1989). These two lines of evidence suggest a potential role of iron-deficiency in limiting hematogenous dissemination of TB among ancient Maya.

A review of modern experimental and epidemiological studies demonstrates the necessity of adequate serum and tissue iron for development of TB. Like most microbial pathogens, mycobacteria require iron for their existence and growth. In the case of $M$. tuberculosis, for example, limitation of iron limits growth in vitro (McReady \& Ratledge 1978, Lundrigan et al. 1997). As might be expected, one line of defense that mammals have evolved against potential microbial invaders is a system to sequester iron and limit pathogen access. Host proteins such as transferrin and lactoferrin chelate extracellular iron, while intracellular iron can be stored by the protein ferratin (Finklestein et al. 1983). Upon infection, serum iron shifts to immune cells in the reticuloendothelial system (Finklestein et al. 1983, Olakanmi et al. 2002), and assimilation of dietary iron is also restricted (Ratledge 2004).

In their turn, obligate pathogens such as $M$. tuberculosis have evolved their own chelators (called side- 
rophores) to compete with (or even remove iron from) the host's iron-binding proteins (Gobin \& Horwitz 1996). Such competition is of great importance for both host and pathogen, as “[i]ron availability... and the bacterium's efforts to circumvent ...[its]... restriction are critical determinants of the outcome of infection with M. tuberculosis" (De Voss et al. 1999). Ratledge (2004) reviews experimental research on mycobacterial siderophores. In vitro, the siderophore mycobactin is produced in response to iron deficiency. Laboratory research shows that mycobactin synthesis reaches a maximum when the culture medium is iron-deficient. It is suggested that in host tissues in vivo, extracellular siderophores acquire iron from the host and transmit it to mycobactin. When the mycobacterium receives iron, it signals the repression of mycobactin synthesis, so the level of mycobactin likely remains low when iron is sufficient. The question, then, is to what extent iron deficiency in the host is necessary before synthesis of siderophores begins. Further, if hosts have very little tissue iron, there will be little iron available to the mycobacterium regardless of siderophore synthesis. Ratledge (2004) cautions against food or supplements rich in iron for TB patients: "Mild anaemia is of positive benefit to the patient particularly in the early stages of the disease as this prevents the mycobacteria gaining the iron they need for growth" ( $p$. 124).

Several studies have documented the role of host iron stores in the outcome of infection with mycobacteria. Ironoverload in a certain strain of lab mouse was found to be "an exacerbating cofactor for tuberculosis" (Schaible et al. 2002). Multiplication of M. tuberculosis in mouse lungs and spleens was shown by Lounis et al. (2001) to be enhanced when iron was administered, while the number of bacilli was reduced in controls. Resistance to another pathogenic mycobacterium, M. avium, is also decreased in the presence of excess iron (De Voss et al. 1999). For example, mice fed iron-rich diets developed disease more rapidly than control mice, and had a higher M. avium bacterial load than those eating a regular diet (Dhople et al. 1996). Further, when iron-supplementation was combined with beef fat, the mice developed disseminated disease faster with smaller doses of M. avium. In humans, M. avium is a typical opportunistic pathogen of the immune-compromised, and experiments have shown that the rate of $M$. avium complex replication in human immune cells directly correlates with iron concentration (reviewed in De Voss et al. 1999).

Given the importance of iron availability to the outcome of infection with mycobacteria, it is not surprising that pulmonary TB patients are typically anemic (Morris et al. 1989), and it has been suggested that the anemia of infectious and chronic disease is an immune defense mechanism (Kent et al. 1994). In fact, Murray et al. (1978) point out that Armand Trousseau understood the importance of iron availability in TB patients as early as 1868 , and in 1872 he warned against iron-supplementation for recovering patients, as this had been observed to cause a relapse of active disease.

In 1978, Murray and colleagues examined the effects of iron supplementation on the incidence of various types of infections. Iron-deficient Somali nomads were either given a course of ferrous sulfate or a placebo for 30 days. More than five times as many iron-supplemented individuals developed infections (including three cases of glandular TB or tubercular mastoiditis) compared to controls. The authors showed that infections in the ironsupplemented individuals were almost certainly due to reactivation of latent infection, and reactivation peaked as individuals neared normal iron status.

The effects of high levels of dietary iron were also examined in an autopsy series of black South Africans by Gordeuk et al. (1996). Individuals with high levels of tissue iron were found to be 17 times more likely to have died from TB than those with negligible iron, and there was a dose-response effect of iron level and risk of death by TB. When dietary iron intake was examined in another African group (Gangaidzo et al. 2001), elevated levels were found to increase the risk of active pulmonary TB, as high levels impair the ability of macrophages to suppress growth.

Macrophages are immune cells that are important first responders to infection with $M$. tuberculosis. Their role is to engulf, digest and present portions of foreign pathogens that they encounter. However, M. tuberculosis has developed the ability to live inside macrophages, although their growth inside and outside macrophages can be regulated by iron. Olakanmi et al. (2002) showed that M. tuberculosis requires iron for growth and multiplication within macrophages, and it can acquire this iron either from within the macrophage if it was preloaded prior to the infection, or from outside the cell from the host's transferrin. Further experiments (Serafin-Lopez et al. 2004) showed that iron regulates bacterial growth within macrophages as well as stimulating M. tuberculosis growth outside the macrophages. In mouse-macrophages, iron is crucial for $M$. avium's survival. When infected cells were supplemented with iron, M. avium was able to inhibit the normal process of phagosome maturation by which macrophages digest (and thus kill) invading organisms (Kelley \& Schorey 2003).

Thus it appears that, if host iron is not limited, $M$. tuberculosis can multiply in macrophages, which may eventually burst and allow bacilli into extracellular space, where they may disseminate. This led us to wonder what happens if an individual is anemic and is exposed to $M$. tuberculosis. Is it possible, given the importance of iron for growth of the organisms in the host, that infection will remain latent? Or if disease does develop, will lack of iron tend to limit dissemination due to reduced growth of bacteria? We are currently pursuing this line of questioning, also considering an additional portion of the immune system.

The human complement cascade is a component of innate immunity with multiple functions, including the lysis of foreign cells and the promotion of phagocytosis of antigens and bacterial cells. Upon encountering evidence for infection of cells, a cascade is triggered that culminates with a "Membrane Attack Complex" that creates a pore in the affected cell, penetrating the membrane and bursting the cell. While this works well on some types of infections, the consequences of bursting a cell filled with multiplying $M$. tuberculosis may be to disseminate the organism around the body. 
Experiments have shown that mycobacteria can use the host's complement system to gain entry to macrophages, and Schorey et al. (1997) demonstrated a novel mechanism that only the pathogenic mycobacteria have evolved in order to use the complement system as a means of entering macrophages. We conjectured that it may be possible, as well, that such stimulation of the complement system by pathogenic mycobacteria could also stimulate cell lysis, potentially freeing mycobacteria from infected macrophages and allowing their dissemination throughout the body. The mice experimentally infected with $M$. avium (Dhople et al. 1996), for example, did indeed develop disseminated disease quickly with a very low dose of inoculum when fed extra iron. We underscore, however, that the mechanism by which dissemination occurs is unknown, and therefore our observations concerning the complement system are, at this point, merely speculation. Still, this discussion highlights areas in which future research may shed light upon the archaeological record.

The examples presented in this paper are from areas in which our current research is focusing, in addition to an ongoing ancient DNA component that explores the phylogeny of New World TB in relationship to current reinterpretations of Old World sequences. Our research program seeks to incorporate data and theories from other disciplines, focusing on acquisition of new data as well as examination of that already available in light of recent advances. In this way, we hope to understand past cycles of disease, and to help predict the forms that may be taken by future ones.

\section{ACKNOWLEDGEMENTS}

To Anne Stone and Silvia Smith for comments on the manuscript, to Lori Wright for unpublished data, and to Vera Tiesler Blos for advice on Maya archaeology.

\section{REFERENCES}

Allison MJ, Mendoza D, Pezzia A 1973. Documentation of a case of tuberculosis in pre-Columbian America. Am Rev Respir Dis 107: 985-991.

Anderson RM, May RM 1982. Population Biology of Infectious Diseases, Springer-Verlag, Berlin.

Arriaza B, Salo W, Aufderheide AC, Holcomb TA 1995. PreColumbian tuberculosis in Northern Chile: molecular and skeletal evidence. Am J Phys Antropol 98: 37-45.

Baker L, Brown T, Maiden MC, Drobniewski F 2004. Silent nucleotide polymorphisms and a phylogeny for Mycobacterium tuberculosis. Emerg Infect Dis 10: 1568-1577.

Bautista Martínez J, Romano Pacheco A 2003. Los enanos en Mesoamérica. Un caso del occidente de México. In CS Sáncez, SL Alonso, FO Pedraza(eds), Estudios de Antropología Biológica (V. XI), Conaculta-INAH, Mexico, p. 761-772.

Bellamy RJ, Hill AVS 1998. Host genetic susceptibility to human tuberculosis. In DJ Chadwick, Genetics and Tuberculosis, John Wiley \& Sons, West Sussex, p. 3-23.

Braun M, Cook D, Pfeiffer S 1998. DNA from Mycobacterium tuberculosis complex identified in North American preColumbian human skeletal remains. J Archeol Sci 25: 271277.
Brosch R, Gordon SV, Marmiesse M, Brodin P, Buchrieser C, Eiglmeier K, Garnier T, Gutierrez C, Hewison G, Kremer K, Parsons LM, Pym AS, Samper S, van Soolingen D, Cole ST 2002. A new evolutionary scenario for the Mycobacterium tuberculosis complex. PNAS 99: 3684-3689.

Buikstra JE 1976. The Caribou Eskimo: general and specific disease. Am J Phys Anthropol 45: 351-368.

Buikstra JE 1999. Paleoepidemiology of tuberculosis in the Americas. In G Pálfi, O Dutourk, J Déak, I Hútas (eds), Tuberculosis Past and Present, Golden Book Publishers and Tuberculosis Foundation, Budapest/Szeged, p. 479-494.

Chase DZ 1997. Southern Lowland Maya archaeology and human skeletal remains: interpretations from Caracol (Belize), Santa Rita corozal (Belize), and Tayasal (Guatemala). In SL Whittington, DM Reed (eds), Bones of the Maya, Smithsonian Institution Press, Washington, p.15-27.

Cockburn A 1963. The Evolution and Eradication of Infectious Diseases, The Johns Hopkins Press, Baltimore.

Coe 1990. Tikal Report No. 14, Vol. II, University of Pennsylvania Museum, Philadelphia.

Crane HR, Griffin JB 1959. University of Michigan radiocarbon dates IV. Am J Sci Radiocarbon (Suppl. 1): 173-198.

D’Ambrosio D, Panina-Bordignon P, Rogge L, Sinigaglia F 1998. Molecular mechanisms of $\mathrm{T}$ helper cell differentiation and tissue-specific migration. Cur Top Microbiol Imm 246: 117 122.

De Voss JJ, Rutter K, Schroeder KG, Barry CE III 1999. Iron acquisition and metabolism by mycobacteria. J Bacteriol 181: 4443-4451.

Dhople AM, ibanez MA, Poirer TC 1996. Role of iron in the pathogenesis of Mycobacterium avium infection in mice. Microbios 87: 77-87.

Dunn PL, North RJ 1995. Virulence ranking of some Mycobacterium tuberculosis and Mycobacterium bovis strains according to their ability to multiply in the lungs, induce lung pathology, and cause mortality in mice. Infect Immun 63: 3428-3437.

Ewald P 1994. Evolution of Infectious Disease, Oxford University Press, Oxford.

Fanning EA 1994. Mycobacterium bovis infection in animals and humans. In PDO Davies, Clinical Tuberculosis, Chapman and Hall Medical, London, p. 351-364.

Finklestein RA, Sciortino CV, McIntosh MA 1983. Rev Infect Dis 5: 5759-5777.

Gangaidzo It, Moyo VM, Mvundura E, Aggrey G, Murphree NL, Khumalo H, Saungweme T, Kasvosve I, Gomo ZAR, Rouault T, Boelaert JR, Gordeuk 2001. Association of pulmonary tuberculosis with increased dietary iron. $J$ Infect Dis 184: 936-939.

García-Frías JE 1940. La tuberculosis en los antiguous Peruanos. Actualidad Médica Peruana 5: 274-291.

Gobin J, Horwitz MA 1996. Exochelins of Mycobacterium tuberculosis remove iron from human iron-binding proteins and donate iron to mycobactins in the M. tuberculosis cell wall. J Exp Med 183: 1527-1532.

Gordeuk VR, McLaren CE, MacPhail AP, Deischsel G, Bothwell TH 1996. Associations of iron overload in Africa with hepa- 
tocellular carcinoma and tuberculosis: Strachan's 1929 thesis revisited. Blood 87: 3470-3476.

Gutierrez MC, Brisse S, Brosch S, Fabre M, Omaïs B, Marmiesse M, supply P, Vincent V 2005. Ancient origin and gene mosaicism of the progenitor of Mycobacterium tuberculosis. PLOS Pathogens 1: 1-7.

Haviland W 1967. Stature at Tikal, Guatemala: implications for ancient Maya demography and social organization. Am Antiq 32: 316-325.

Hurtado AM, Hill KR, Rosenblatt W, Bender J, Scharmen T 2003. Longitudinal study of tuberculosis outcomes among immunologically naive Aché natives of Paraguay. Am J Phys Anthropol 121: 134-150.

Hrdliçka A 1909. Tuberculosis Among Certain Indian Tribes of the United States, Smithsonian Institution, Washington DC.

Judd NM 1954. The Material Culture of Pueblo Bonito, Smithsonian Institution Miscellaneous Collections v. 147, Washington DC.

Kelley VA, Schorey JS 2003. Mycobacterium's arrest of phagosome maturation in macrophages requires Rab5 activity and accessibility to iron. Mol Biol Cell 14: 3366-3377.

Kent S, Weinberg ED, Stuart-Macadam P 1994. The etiology of the anemia of chronic disease and infection. J Clin Epidemiol 47: 23-33.

Kuszewski K, Brydak L 2000. The epidemiology and history of influenza. Biomed Pharmac 54: 188-195.

Lichtor J, Lichtor A 1952. Paleopathological evidence suggesting pre-Columbian tuberculosis of the spine. J Bone Joint Surg 39A: 1398-1399.

Lorenzo C 1995. La circulación. In L Manzanill, LL Luján (eds), Historia Antigua de México, v.III, El Horizonte Posclásico y Algunos Aspectos Intelectuales de las Culturas Mesoamericanas, Consejo Nacional para la Cultura y las Artes, INAH-IIA, Mexico, p. 355-381.

Lounis N, Truffot-Pernot C, Grosset J, Gordeuk VR, Boelaert JR 2001. Iron and Mycobacterium tuberculosis infection. J Clinic Virol 20: 123-126.

Lundrigan MD, Arceneaux JEL, Zhu W, Byers BR 1997. Enhanced hydrogen peroxide sensitivity and latered stress protein expression in iron-starved Mycobacterium smegmatis. BioMetals 10: 215-225.

Massey VK, Steele DG 1997. A Maya skull pit from the Terminal Classic Period, Colha, Belize. In SL Whittington, DM Reed (eds), Bones of the Maya, Smithsonian Institution Press, Washington, p. 62-77.

McReady KA, Ratledge C 1978. Amounts of iron, heme and related compounds in Mycobacterium smegmatis grown in various concentrations of iron. Biochem Soc Trans 6: 421423.

Morris CDW, Bird AR, Nell H 1989. The haematological and biochemical changes in severe pulmonary tuberculosis. Quarterly J Med (New Series) 73: 1151-1159.

Morse D 1961. Prehistoric tuberculosis in America. Am Rev Resp Dis 83: 489-504.

Mosmann TR, Cherwinski H, Bond MW, Giedlin MA, Coffman RL 1986. Two types of murine helper T cell clone. 1. Definition according to profiles of lymphokine activities and se- creted proteins. J Immunol 136: 2348-2357.

Mulligan CJ, Hunley K, Cole S, Long JC 2004. Population genetics, history, and health patterns in Native Americans. Ann Rev Genomics Hum Genet 5: 295-315.

Mullis KB, Faloona FA 1987. Specific synthesis of DNA in vitro via a polymerase-catalyzed chain reaction. Meth Enzymol 155: 335-350.

Murray MJ, Murray AB, Murray MB, Murray CJ 1978. The adverse effect of iron repletion on the course of certain infections. Bri Med J 2: 1113-1115.

Myers JA, Steele JH 1969. Bovine Tuberculosis Control in Man and Animals, Warren H Green, St. Louis.

Olakanmi O, Schlesinger LS, Ahmed A, Britigan BE 2002. Intraphagosomal Mycobacterium tuberculosis acquires iron from both extracellular transferrin and intracellular iron pools. J Biol Chem 277: 49727-49734.

Power CA, Wei G, Bretscher PA 1998. Mycobacterial dose defines the Th1/Th2 nature of the immune response independently of whether immunization is administered by the intravenous, subcutaneous, or intradermal route. Infec Immun 66: 5743-5750.

Prager C 2002. Enanismo y gibosidad: as personas afectadas y su identidad en la sociedad maya del tiemp prehispánico. In VT Blos, R Cobos, MG Robertson (eds), La Organización Social entre los Mayas, Memoria de la Tercera Mesa Redonda de Palenque (V. 2), INAH, Universidad Autónoma de Yucatán, Mexico, p. 35-67.

Ratledge C 2004. Iron, mycobacteria, and tuberculosis. Tuberculosis 84: 110-130.

Requena A 1945. Evidencia de tuberculosis en la América preColumbia. Acta Venezoelana 1: 1-20.

Rich AR 1944. Pathogenesis of Tuberculosis, Thomas, Chicago.

Ritchie WA 1952. Paleopathological evidence suggesting preColumbian tuberculosis in New York State. Am J Phys Anthropol 10: 305-310.

Roberts CA, Buikstra JA 2003. The Bioarchaeology of Tuberculosis, University Press of Florida, Gainesville.

Rothschild BM, Martin LD, Lev G, Bercovier H, Bar-Gal GK, Greenblatt C, Donoghue H, Spigelman M, Brittain D 2001. Mycobacterium tuberculosis complex DNA from an extinct bison dated 17,000 years before the present. Clin Infect Dis 33: 305-311.

Salo WL, Aufderheide AC, Buikstra J, Holcomb TA 1994. Identification of Mycobacterium tuberculosis DNA in a preColumbian mummy. PNAS 91: 2091-2094.

Salzano FM 2002. Molecular variability in Amerindians: widespread but uneven information. Ann Braz Acad Sci 74: 223-263.

Sander B, Skansén-Saphir U, Damm O, Hakansson L, Andersson J 1995. Sequential production of Th1 and Th2 cytokines in response to live bacillus Calmette-Guérin. Immunology 86: 512-518.

Saul JM, Saul FP 1997. The Preclassic skeletons from Cuello. In SL Whittington, DM Reed (eds), Bones of the Maya, Smithsonian Institution Press, Washington, p. 28-50. 
Schaible UE, Collins HL, Priem F, Kaufmann SHE 2002. Correction of the iron overload deficit in $\beta-2$ microglobulin knockout mice by lactoferrin abolishes their increased susceptibility to tuberculosis. J Exp Med 196: 1507-1513.

Schorey JS, Carroll MC, Brown EJ 1997. A macrophage invasion mechanism of pathogenic mycobacteria. Science 277: 1091-1093.

Serafin-López J, Chacón-Salinas R, Munoz-Cruz S, EncisoMoreno JA, Estrada-Parra, SA, Estrada-Garcia I 2004. The effect of iron on the expression of cytokines in macrophages infected with Mycobacterium tuberculosis. Scand J Immunol 60: 329-337.

Sharer RJ 1994. The Ancient Maya, 5th ed., Stanford University Press, Stanford.

Sousa AO, Salem JL, Lee FK, Vercosa MC, Cruaud P, Bloom BR, Lagrange PH, David HL 1997. An epidemic of tuberculosis with a high rate of tuberculin anergy among a population previously unexposed to tuberculosis, the Yanomami Indians of the Brazilian Amazon. PNAS 94: 13227-13232.

Stead WW 1997. The origin and erratic global spread of tuberculosis. How the past explains the present and is the key to the future. Clin Chest Med 18: 65-77.

Stead WW 2000. Reply to Trembly. Paleopathol Newsl 112: 14-15.

Stead WW 2001. Variation in vulnerability to tuberculosis in America today: random, or legacies of different ancestral epidemics. IJTLD 5: 807-814.

Stead WW, Eisenach KD, Cave MD, Beggs ML, Templeton GL, Thoen CO, Bate JH 1995. When did Mycobacterium tuberculosis infection first occur in the New World? Resp and Crit Care Med 151: 1267-1268.
Surcel H-M, Troye-Blomberg M, Paulie S, Andersson G, Moreno C, Pasvol G, Ivanyi J 1994. Th1/Th2 profiles in tuberculosis, based on the proliferation and cytokine response of blood lymphocytes to mycobacterial antigens. Immunology 81: 171176.

Tiesler V, Cucina A 2005. Las enfermedades del la aristocracia Maya en el Clásico. Arqueologia Mexicana 13: 42-47.

Van Soolingen D, Qian L, de Haas PEW, Douglas JT, Traore H, Portaels F, Qing HZ, Enhksaikan D, Nymadawa P, van Embden JDA 1995. Predominance of a single genotype of $M y$ cobacterium tuberculosis in countries of East Asia. J Clin Microbiol 33: 3234-3238.

Whittington SL 1989. Characteristics of Demography and Disease in Low-status Maya from Classic Period Copan, Honduras, PhD Thesis, The Pennsylvania State University, University Park.

Whittington SL, Reed DM 1997. Commoner diet at Copán: insights from stable isotopes and porotic hyperostosis. In SL Whittington, DM Reed (eds), Bones of the Maya, Smithsonian Institution Press, Washington, p. 157-170.

Wilbur AK 2005. Genetics of Host Susceptibility to Tuberculosis in Two Native Paraguayan Populations: Aché and Avá, PhD Thesis, The University of New Mexico, Albuquerque.

Wright LE 1994. Paleopathology Newsletter Supplement, Scientific Program Thirty-Second Annual Meeting (North America), p. 17-18.

Wright LE 2005. Bilateral club foot: a case study from Tikal, Guatemala. Poster presented at Annual Meeting of the Paleopathology Association, Milwaukee, WI.

WHO-World Health Organization 2003. Influenza. Fact Sheet No. 211. WHO, Geneve. 